6. Gogunov EN, Martyanov BI. Psychology of physical education and sports: Ucheb. posobie dlya stud. vyissh. ped. ucheb. zavedeniy Moskva: Izdatelskiy tsentr. "Akademiya"; 2004. 224 p.

7. Dalinina TA, Zedgenidzeze VYa, Stepina NM. In the World of Children's Emotions: A Handbook for Practitioners of the DOU Moscow: Ayris-press; 2004. 160 p.

8. Piloyan RA, Suhanov AD. Physical culture as an object of cognition in the aspect of psychological activity. Teoriya i praktika fizicheskoy kulturyi [Internet]. 2000 [cited 2018 бep 22].

9. Shyian BM. Theory and Methods of Physical Education: Teach: Navch. knyha - Bohdan. 2001. 272 p.

10. Goleman D. Emotional Inteligence. New York: Bantam Books; 2006. 360 p.

11. Carlos Valiente, Jodi Swanson, Nancy Eisenberg. Linking Students' Emotions and Academic Achievement: When and Why Emotions Matter Child. Dev. 2012; 6 (2): 129-35.

Цитування на цю статтю:

Мосійчук ЛВ. Виховання в молодших школярів інтересу до занять з фізичного виховання у системі “школа-сім’я”.Вісник Прикарпатського університету. Серія: Фізична культура. 2019 Листоп 27; 34: 103-111

\begin{tabular}{|c|c|}
\hline Відомості про автора: & Information about the author: \\
\hline $\begin{array}{l}\text { Мосійчук Леонід Васильович - кандидат наук з фі- } \\
\text { зичного виховання і спорту, доцент, Тернопільсь- } \\
\text { кий національний педагогічний університет імені } \\
\text { В. Гнатюка (Тернопіль, Україна) }\end{array}$ & $\begin{array}{l}\text { Mosiychuk Leonid-Candidate of Science in Physical } \\
\text { Education and Sports, Associate Professor, Ternopil } \\
\text { National Pedagogical University named after V. } \\
\text { Hnatyuk (Ternopil, Ukraine) }\end{array}$ \\
\hline $\begin{array}{l}\text { e-mail: leonid.mosiychuk@ gmail.com } \\
\text { https://orcid.org/0000-0002-2756-5795 }\end{array}$ & \\
\hline
\end{tabular}

УДК 796.011.2:796.6

doi: 10.15330/fcult.34.111-124
Дмитро Піонтковський, Богдан Мицкан, Тетяна Мицкан

\title{
РОЗВИТОК ШВИДКІСНИХ І КООРДИНАЦІЙНИХ ЗДІБНОСТЕЙ СПОРТСМЕНІВ 3 ВЕЛОСИПЕДНОГО СПОРТУ ВМХ НА ЕТАПІ ПОЧАТКОВОї ПІДГОТОВКИ
}

Мета. Розробити та експериментально перевірити ефективність програми розвитку швидкісних $i$ координаційних здібностей спортсменів велосипедного спорту ВМХ на етапі початкової підготовки. Методи. У ході дослідження було проведено педагогічний експеримент, який тривав протягом 3 років. На різних етапах експерименту прийняло участь 72 юних велосипедисти ВМX, 36 з яких увійшли до контрольних груп (по 12 учасників у кожній), а 36 - до основних. Очінка рівня розвитку швидкісних здібностей та абсолютних координаційних здібностей здійснювалася за допомогою рухових тестів (біг 30 м, човниковий біг 3 x10 м). Збереження вертикальної стійкості тіла визначали за допомогою тесту С.Я. Бондаревського. 3 метою акиентованого розвитку координаційних здібностей було застосовано комплекси неспецифічних для велоспорту ВМХ вправ, а саме стрибки на батуті. Мотиваційна складова велосипедистів-початківців ВМХ визначалася з використанням методик діагностики особистості на мотивачію до досягнення успіху та уникнення невдач за Т. Елерсом. Психологічний компонент програми двокомпонентного психофізичного впливу, базувався на використанні вербальних засобів психологічної підготовки спортсменів, використання методів психологічної мотивації до виконання неспецифічних вправ. Результати. Доведено, що показники розвитку досліджуваних фізичних здібностей учасників основних груп наприкінці річних макрочиклів тренування під впливом реалізаиії авторської програми вірогідно зросли у порівнянні з аналогічними показниками контрольних груп. Водночас зріс рівень вертикальної стійкості тіла велосипедистів-початківців ВМХ основних груп $i$ на останньому етапі дослідження перевищував нормативи середнього рівня, установлених для європейської популяції у віковій когорті 10-річних спортсменів. При ц̧ьому, виявлено статистично значущу різницю між середньо груповими результатами проходження змагальної дистанції 380 м учасниками основної та контрольної груп на користь юних спортсменів основних груп в усіх трьох річних макроциклах тренування. Висновок. Застосування в групах початкової підготовки спортсменів-велосипедистів ВМХ двокомпонентного психофізичного впливу на розвиток спеціальних фізичних якостей забезпечує інтенсивне удосконалення як ивидкісних $i$ координаційних здібностей, так і вертикальної стійкості, а також покращення результатів змагальної діяльності.

Ключові слова: спортсмени-велосипедисти ВМX, етап початкової підготовки, швидкісні $i$ координаційні здібності, програм двокомпонентного психофізичного впливу. 
To develop and experimentally test the effectiveness of the program of development of speed and coordination abilities of athletes of cycling sports BMX at the stage of initial preparation. Methods. During the study, a pedagogical experiment was conducted that lasted for 3 years. At various stages of the experiment, 72 young BMX cyclists participated, 36 of whom were in control groups (12 participants in each), and 36 - in the main ones. The assessment of the level of development of speed abilities and absolute coordination abilities was carried out by means of motor tests (running $30 \mathrm{~m}$, shuttle running $3 \times 10 \mathrm{~m}$ ). Maintaining the vertical stability of the body was determined using the E.Y. Bondarevsky. For the purpose of accentuated development of coordination abilities, complexes of non-specific BMX exercises, namely jumping on a trampoline, were applied. The motivational component of beginners cycling BMX was determined using the methods of diagnosis of personality motivation to achieve success and avoidance of T. Ehler's failures. Psychological component of the program of two-component psychophysical influence, was based on the use of verbal means of psychological training of athletes, the use of methods of psychological motivation to perform non-specific exercises. Results. It is proved that the indicators of development of the studied physical abilities of participants of the main groups at the end of the annual macrocycles of training under the influence of the author's program implementation significantly increased in comparison with the similar indicators of the control groups. At the same time, the level of vertical stability of the body of cyclists-beginners of BMC of the main groups increased and at the last stage of the study exceeded the norms of the average level established for the European population in the age cohort of 10-year-old athletes. At the same time, a statistically significant difference was found between the average group results of passing the competitive distance of $380 \mathrm{~m}$ by the participants of the main and control groups in favor of young athletes of the main groups in all three annual macrocycles of training. Conclusion. The use of two-component psychophysical influence on the development of special physical qualities in the initial training groups of BMX cyclists provides for intensive improvement of both speed and coordination abilities as well as vertical stability, as well as improvement of the results of competitive activity.

Keywords: BMX athletes-cyclists, initial training stage, speed and coordination abilities, programs of two-component psychophysical influence.

Постановка проблеми та наліз останніх результатів досліджень. Велоспорт BMX є визнаним олімпійським видом, відтак розробка ефективних програм і методів розвитку спеціальних фізичних якостей юних спортсменів відповідає потребам сьогодення (В.Ю. Сизова, 2013) і створює передумови для підготовки вітчизняних велосипедистів ВМХ, орієнтованих на вищі досягнення (П.П. Булатов, Е.П. Лукша, 2014). Відтак специфіка змагально-тренувальної діяльності, складна структура дій у велоспорті ВМХ сприяють розвитку координаційних здібностей і психофізіологічних якостей (В.Г. Медведев, А.С. Дишаков, 2017), від ступеню розвитку яких залежить ефективність початкової підготовки юних спортсменів (В.М. Платонов, 2015; А.М. Козак, 2016). Водночас, молодший шкільний вік відрізняється особливою сенситивністю щодо застосування інноваційних методів навчання (Я. Кушнір, 2015), і якраз у цьому віці фізичні навантаження доцільно здебільшого спрямовувати на розвиток фізичних i психофізіологічних якостей (Н.В. Багинская, А.В. Федоряка, А.Л. Станіцкевич, 2015), вольове загартування, формування наполегливості (С. Воропай, М. Нудьга, С. Собко, Н. Собко, 2016).

Збіг вікових періодів найбільш ефективного педагогічного впливу та доволі сприятливого для формування координаційних здібностей та психофізіологічного статусу дитячого організму (В.М. Кириченко, 2015) особливо актуалізує питання методики розвитку спеціальних фізичних та психофізіологічних якостей велосипедистівпочатківців.

У теперішній час вченими доведено вплив занять екстремальними видами рухової активності на розвиток координаційних здібностей підлітків (Піонтковський Д, Мицкан Б., 2016; Ю.І. Іванишин, 2018), розроблено програму підвищення ефективності техніки рухових дій в видах спорту зі складно координаційною структурою руху (В.О. Кашуба, 2017), вивчено особливості проблеми і перспективи розвитку екстремального виду велосипедного спорту (ВМХ) (М.С. Пруднікова, 2014), запропоновано рекомендації щодо психофізичної підготовки спортсменів у велоспорті ВМХ (М.М. Ковилін, 
А.А. Передельский, 2014), представлено експериментальні розробки з програмування і планування навчально-тренувального процесу велогонщиків BMX-RACE (M.M. Ковилін, А.А. Передельский, 2015), програму тестування координаційних здібностей юних спортсменів BMX (А.Г. Карпеєв, А.А. Горский, 2012). Водночас серед сучасних наукових розробок з підготовки початківців у велоспорті ВМХ важко знайти чіткі програми розвитку спеціальних фізичних якостей, зокрема координаційних здібностей та психофізіологічних якостей.

3 урахуванням вищенаведеного актуальність дослідження видається очевидною вона зумовлена важливістю розвитку координаційних здібностей у юних велосипедистів на тлі браку науково-методичних рекомендацій, чітко визначених засобів та методичних прийомів щодо застосування для цього сучасного, ефективного та популярного серед дітей велоспорту ВМХ.

Мета дослідження - розробити та експериментально перевірити ефективність програми розвитку спеціальних фізичних якостей юних спортсменів велосипедного спорту BMX на початковому етапі підготовки.

Методи та організація дослідження. У ході дослідження було проведено педагогічний експеримент, який тривав протягом 3 років. На різних етапах експерименту прийняло участь 72 юних велосипедисти ВMX, 36 з яких увійшли до контрольних груп (по 12 учасників у кожній), а 36 - до основних.

Процедура розподілу, під час якої 24 велосипедисти-початківці розподілялися по 12 учасників на контрольну і основну групи, проводилася кожного року на початку річного циклу підготовки (у вересні).

Оцінка рівня розвитку швидкісних здібностей та абсолютних координаційних здібностей здійснювалася за допомогою рухових тестів (біг 30 м, човниковий біг $3 \times 10$ м). Збереження вертикальної стійкості тіла визначали за допомогою тесту Є.Я. Бондаревського [1].

3 метою акцентованого розвитку координаційних здібностей було застосовано комплекси неспецифічних для велоспорту ВМХ вправ, а саме стрибки на батуті.

Мотиваційна складова велосипедистів-початківців ВМХ визначалася 3 використанням методик діагностики особистості на мотивацію до досягнення успіху та уникнення невдач за Т. Елерсом.

Як психологічний компонент програми двокомпонентного психофізичного впливу, заснованого на використанні вербальних засобів психологічної підготовки спортсменів, використовувався метод психологічної мотивації до виконання неспецифічних вправ.

На першому етапі дослідження (2011 р.- серпень 2012 р.) було проаналізовано та узагальнено дані наукової літератури, які дозволили обгрунтувати обраний напрям дослідження й конкретизувати його фокус саме на розвитку координаційних здібностей юних спортсменів 3 велоспорту ВМХ 3 використанням додаткових психофізичних вправ.

На другому етапі дослідження (вересень 2012 р. - червень-липень 2015 р.) кожного року проводився педагогічний експеримент за наступною схемою:

a) первинний констатуючий педагогічний експеримент у вересні на початку річного циклу підготовки для учасників основної та контрольної груп, спрямований на встановлення існуючих до застосування програми тренування характеристик розвитку швидкісних та координаційних здібностей;

б) формувальний педагогічний експеримент протягом 10-ти місяців (вересеньчервень) тільки для учасників основної групи, спрямований на розвиток швидкісних $\mathrm{i}$ 
координаційних здібностей шляхом застосування додаткового до навчально-тренувальної програми двокомпонентного психофізичного впливу;

в) вторинний констатуючий педагогічний експеримент у червні наприкінці 10-ти місячного циклу підготовки для учасників основної та контрольної груп, спрямований на встановлення існуючих після застосування програми тренування характеристик розвитку швидкісних та координаційних здібностей.

г) оцінювання спортивних досягнень учасників основної та контрольної груп наприкінці річного циклу підготовки (червень-липень) способом реєстрації часу проходження дистанції 380 м. на контрольних змаганнях з велоспорту ВМХ.

До складу груп початкової підготовки з велоспорту ВМХ (з вересня 2012 р. по червень-липень 2013 р.), увійшло по 12 учасників основної та контрольної груп, усього 24 особи чоловічої статі віком 9-10 років.

Основні методи спортивного тренування юних спортсменів основної та контрольної груп початкової підготовки, які брали участь у педагогічному експерименті, відповідали умовам і вимогам навчально-тренувальних програм з велоспорту ВМХ для дітей відповідного віку.

Результати дослідження і дискусія. Структура програми розвитку швидкісних i координаційних здібностей складалася 3 двох компонентів: фізичного та психологічного впливу.

Зміст компоненту фізичного впливу являв собою сукупність спортивних вправ у стрибках на батуті, акробатичній доріжці та подвійному мінітрампі для груп початкової підготовки СДЮСШОР [210], які застосовувалися додатково до програми ДЮСШ 3 велосипедного спорту ВМХ. Змістовне призначення фізичного компоненту двокомпонентного психофізичного впливу полягало в тому, що він фактично виконував роль додаткового, неспецифічного для велоспорту ВМХ впливу фізичними навантаженнями складнокоординаційного характеру, які мали позитивно відбитися на рівні розвитку координаційних здібностей учасників педагогічного експерименту. Спеціальний комплекс спортивних вправ на батуті відображений в табл.1.

Таблиия 1

\begin{tabular}{|l|l|l|l|}
\hline № & Вправи & Спеціальний комплекс вправ на батуті \\
\hline 1 & $\begin{array}{l}\text { Стрибок } \\
\text { вгору, на } \\
\text { спину } \\
\text { встати на } \\
\text { ноги }\end{array}$ \\
\hline 2 & $\begin{array}{l}\text { Розгойду } \\
\text { вання на } \\
\text { спині }\end{array}$ \\
\hline
\end{tabular}


Піонтковський Дмитро, Мицєкан Богдан, Мицєкан Тетяна. Розвиток швидкісних і координаційних ...

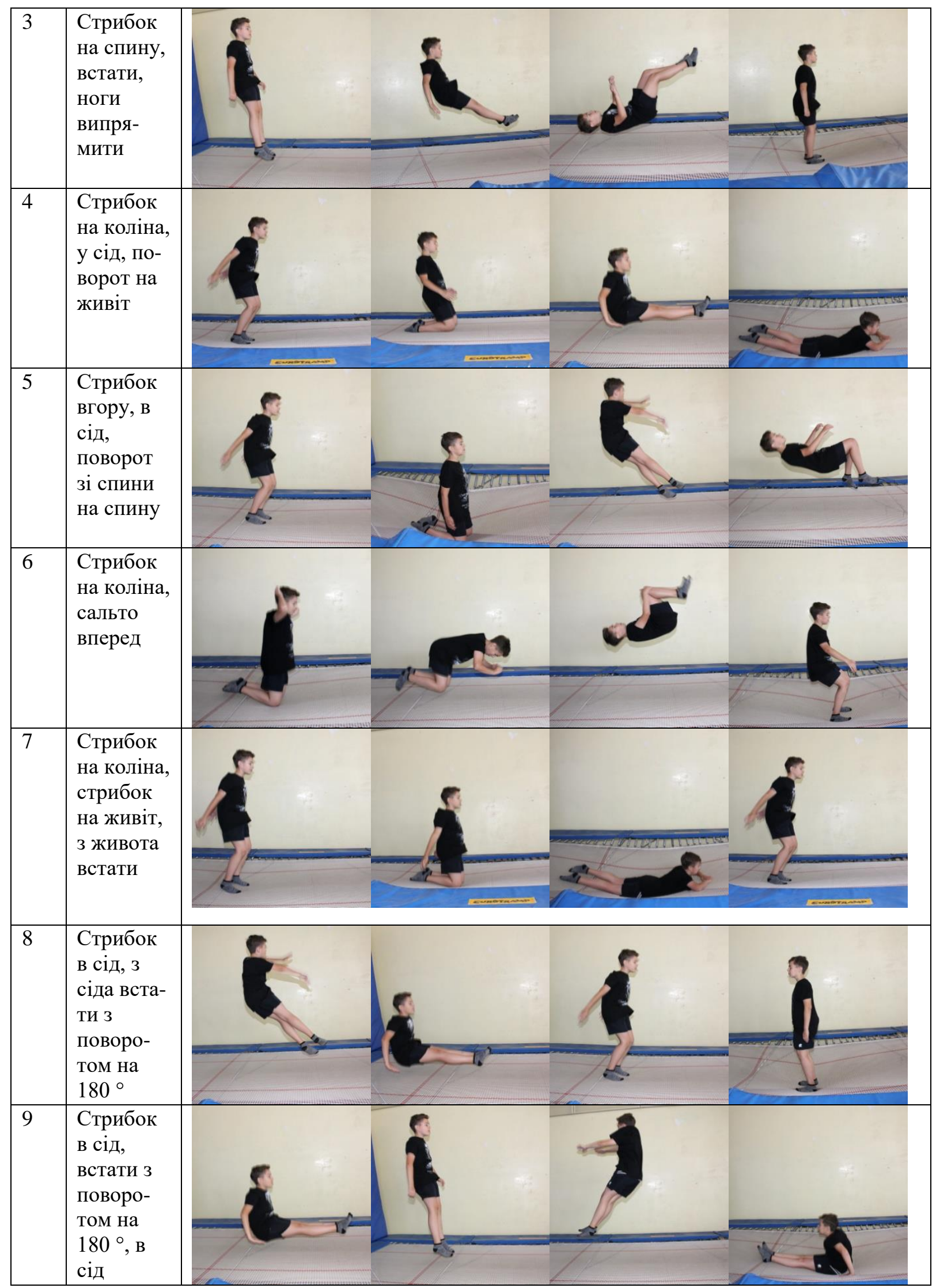




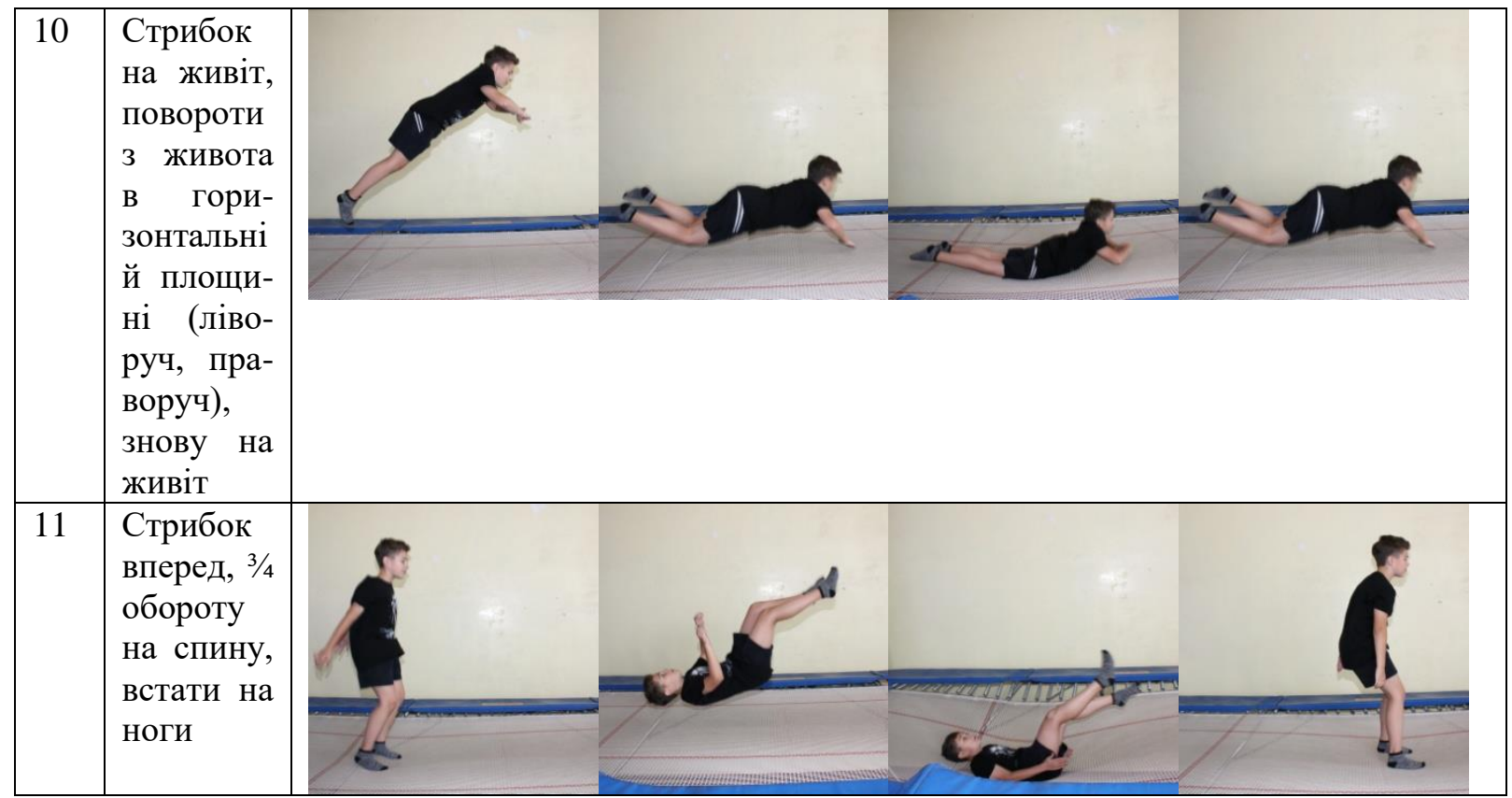

Технологія реалізації авторської програми фізичних навантажень у методичному аспекті характеризувалася такими складовими.

Необхідне обладнання: стандартний спортивний батут, з усіх боків обкладений травмобезпечними акробатичними матами.

Обсяг навантажень: час одного заняття - 30 хвилин; кількість занять на тиждень 3; кількість тренувального часу протягом 10-и місяців експерименту - 60 годин. Протягом одного заняття кожний учасник для виконання вправ здійснював шість-сім підходів середньою тривалістю 25-35 с.

3міст рухових дій в одному niдxодi: учасники намагалися спочатку вивчити, а згодом якомога краще виконати першу із двох обов'язкових вправ класифікаційної програми III юнацького розряду з стрибків на батуті, котра являла собою набір із п'яти послідовно безперервно виконуваних елементів:

1) стрибок із основної стійки (вертикально на ногах) в положення сидячи;

2) стрибок на ноги (повернення в основну стійку);

3) стрибок з ніг на ноги з групуванням у безопорному стані;

4) стрибок “чверть сальто" вперед на живіт;

5) стрибок “чверть сальто" назад на ноги [5].

Протягом перших п’яти занять практичному виконанню вправ передували стандартні педагогічні методи (роз'яснення, показ тренера, демонстрація відеозапису зразкового виконання), які традиційно застосовуються на першому етапі в групах початкової підготовки для ознайомлення з технікою стрибків на батуті.

Оиінка якості виконання вправ (виставлення оцінок за бальною шкалою, схвалення або несхвалення педагогом тощо) навмисно не проводилася (окрім необхідної допомоги у вигляді поточних зауважень за результатами педагогічного спостереження щодо правильності техніки виконання стрибків) зважаючи на те, що мотивація учасників до самовдосконалення у неспецифічних для велоспорту BMX вправах із стрибків на батуті мала створюватися винятково в спосіб спеціального психологічного впливу.

Зміст компоненту психологічного впливу являв собою комплекс методів психологічної мотивації до виконання неспецифічних для велоспорту ВМХ вправ зі стрибків на батуті. 
Цей другий компонент як і перший застосовувався винятково для основної групи учасників педагогічного експерименту додатково до програми ДЮСШ як психологічний компонент програми двокомпонентного психофізичного впливу. Потреба в його застосуванні була зумовлена тією обставиною, що стрибки на батуті не є типовим засобом навчально-тренувальної роботи у велоспорті. Відтак учасникам основної групи могло бути незрозуміло, для чого застосовуватимуться такі вправи, тим більше, що вони були не тільки незвичними й незрозумілими, а як усе нове викликали природне побоювання неуспіху в опануванні, та ще й острах травмування. У подібних обставинах, як указують фахівці з психології спорту, необхідна спеціальна психологічна підготовка, спрямована на створення відповідної мотивації учасників та подолання страху $[6,12,23,26,27$,$] .$

Технологія реалізаиії авторської програми психологічної підготовки в методичному аспекті характеризувалася такими складовими. Основною формою організації психологічного впливу було вербальне спілкування з учасниками основної групи. Словесні формулювання, емоційна інтенсивність і невербальне супроводження вербального спілкування в загальному сенсі визначалися й структурувалися з урахуванням практики застосовування традиційних вербальних методів впливу, які використовуються в психології спорту; правила авторитету (з переліку шести основних правил, які за Р. Чалдині [26] забезпечують ефективність переконання); окремих неімперативних способів психологічного впливу (прохання, порада, переконання, схвалення, підтримка, вселяння) у викладенні О. Матвєєва [15] та окремих елементів псі-програмування з 4-компонентної (маніпуляція, програмування, тиск, атака) системи методів психологічного впливу за В. Дерюгіним [5], які використовуються в процесі інструктажу й навчання (одноманітність і константність в образах, точність і наполегливість у діях, однозначність і унікальність у словах) з метою створення алгоритмів інтелекту й формування стереотипів поведінки.

З урахуванням викладеного були обрані такі параметри технології психологічного впливу.

Обсяг психологічних навантажень: час одного заняття - 15 хвилин;

-кількість занять на тиждень - 3; кількість часу впливу протягом 10 місяців експерименту - 30 годин.

Основна форма заняття - групова співбесіда (за необхідності в ряді випадків використовувалася додаткова форма психологічного впливу - індивідуальна бесіда 3 учасниками, які за результатами педагогічного спостереження потребували додаткової допомоги).

Основний зміст заняття був структурований на дві приблизно рівні частини: a) мотиваційна (переконання в доцільності виконання незвичних вправ); б) стверджувальна (спрямована на подолання побоювань неуспіху у виконанні незвичних вправ, вселяння впевненості у своїх силах та досягненні позитивного результату).

У мотиваційній частині переважно застосовувалося переконання як метод впливу на свідомість через звернення до власного судження особистості, яке формується внаслідок роз'яснення сутності явища, його причинно-наслідкових зв'язків та особистої значимості для учасника успішного опанування запропонованими вправами [14]. Для усвідомлення учасниками складнокоординаційної сутності вправ у стрибках на батуті та причинно-наслідкових зв'язків між виконанням цих вправ і результатами в основному виді спорту (велоспорті ВМХ) застосовувалися: вербальне роз'яснення подібності структури одиночної рухової дії у складі локомоцій в обох видах спорту; демонстрація відеоматеріалів, де відомі ВMX-рейсери легко виконують вправи 3 арсеналу інших складнокоординаційних видів спорту (акробатичне сальто, стрибок 3 
трампліну у воду, сальто на батуті тощо); вербальний коментар зв'язку причини (високого рівня розвитку координаційних здібностей, досягнутого через використання неспецифічних вправ) та наслідку - високих результатів у велоспорті ВМХ, які демонструють показані у відеоматеріалі відомі ВМХ-рейсери.

Для посилення ефективності переконання додатково застосовувалися психологічні прийоми, спрямовані згідно з третім правилом Р. Чалдині (“переконання засноване на авторитеті”, тобто перед спробою переконання аудиторії важливо дати зрозуміти, що знання і досвід ведучого заслуговують на довіру [15]), на піднесення авторитету тренера-викладача, який проводив заняття. 3 цією метою інший тренер-викладач, який начебто випадково опинявся в аудиторії перед початком заняття, привертав увагу учасників заняття до позитивних досягнень тренера-ведучого короткими (менше однієї хвилини) словесними формулами відповідного змісту (наприклад: “Він знає, що каже виховав вже два майстри міжнародного класу”, “Минулого року його команда виграла чемпіонат країни" тощо).

У стверджувальній частині заняття переважно застосовувався метод вселяння 3 метою подолання побоювань неуспіху і створення впевненості у власних силах щодо успішного виконання неспецифічних вправ.

Невербальне вселяння здійснювалося за допомоги демонстрації відеоматеріалу, де комплекс вправ, яким мали опанувати учасники експерименту, легко виконувався дітьми значно молодшого від учасників віку (7-річні учні з групи стрибунів на батуті). Ведучий вербально коментував відеопоказ короткими формулюваннями (наприклад: “Бачите, як це безпечно”, “Це дуже легко навіть маленькій дитині” тощо).

Власне вербальне вселяння здійснювалося за формою емоційно-вольового впливу (інші форми, як-от сильне умовляння та/або тиск [24] не застосовувалися з огляду на вік молодших школярів) за допомоги словесних формул стимулюючого характеру (наприклад: “Це може кожний з вас, потрібне лише бажання”, "Ви можете це зробити, ви цілком здатні на це” тощо). Притому враховувалися стандартні методичні рекомендації щодо особливостей організації такого впливу (зниження рівня аргументації з боку ведучого і критичності сприйняття змісту вправ учасниками, забезпечення посиленої, але мало аргументованої довіри учасників до ведучого, посилена орієнтація учасників на форму і джерело вселяння, а не на його зміст [23]. Відповідно підбиралася й емоційна інтенсивність словесних формулювань.

Крім того, окремі методи індивідуального психологічного впливу застосовувалися, за потреби, під час практичного виконання основною групою учасників експерименту додаткової програми фізичних навантажень безпосередньо у стрибках на батуті. Цими методами, залежно від успішності конкретної ситуації, яка складалася в результаті чергового підходу певного учасника до батуту для виконання рухових дій, були порада, схвалення, підтримка та розрада, методичні особливості застосування яких відповідали прийнятим рекомендаціям [24].

У загальному сенсі застосування всіх методичних прийомів, пов'язаних з реалізацією психологічного компоненту програми двокомпонентного психофізичного впливу було підпорядковане настановам, визначеним численними дослідженнями закономірностей формування особистісної мотивації у юних спортсменів і ролі тренера в цьому процесі (набагато значнішої, ніж у тренуванні дорослих) [28] та одинадцятьом рекомендаціям 3 психологічної підготовки для дитячих тренерів, визначеним Ф. Смолом, Р. Смітом і М. Вайсом [21, 29, 30] щодо уваги до деталей виконання завдань, вербального та невербального щирого схвалення і заохочення зусиль і результатів дитини, реалістичності в оцінках і очікуваннях педагога, застосування демонстраційних прийомів, зміни видів діяльності, цільової видозміни правил, виправлення 
помилок разом із схваленням, улаштування зовнішніх сприятливих умов для подолання страху та перманентного надихання дітей.

Ефективність запропонованої програми і технології іiі реалізації перевірялась за допомогою педагогічного експерименту. Доведено, що до початку експерименту статистично значущих відмінностей між швидкісними та абсолютними координаційними здібностями велосипедистів-початківців BMX не спостерігалось (p>0,05). Проте показники розвитку досліджуваних здібностей учасників основних груп наприкінці річних макроциклів тренування під впливом реалізації авторської методики статистично значуще $(\mathrm{p}<0,05)$ зросли у порівнянні з аналогічними показниками на початку річних макроциклів тренування (табл. 3). Водночас, показники вертикальної стійкості тіла велосипедистів-початківців ВМХ основних груп під впливом запропонованої програми наприкінці річних макроциклів тренування статистично значуще $(p<0,05)$ зросли як у порівнянні з вказаними показниками на початку річних макроциклів тренування, так і порівняно з показниками учасників контрольних груп і на останньому етапі дослідження перевищували нормативи середнього рівня, установлених для європейської популяції у віковій когорті 10-річних школярів.

Таблиия 3

Показники швидкісних й координаційних здібностей юних велосипедистів ВМХ на різних етапах педагогічного експерименту $(\mathbf{n}=\mathbf{3 6})$

\begin{tabular}{|c|c|c|c|c|c|}
\hline \multirow{3}{*}{ 胥 } & \multirow{3}{*}{ Групи учасників експерименту } & \multicolumn{4}{|c|}{ Вимірювані показники } \\
\hline & & \multicolumn{2}{|c|}{ Біг 30 м, с } & \multicolumn{2}{|c|}{$\begin{array}{c}\text { Човниковий біг } \\
3 \times 10 \text { м, с }\end{array}$} \\
\hline & & $\bar{x}$ & $S$ & $\bar{x}$ & $S$ \\
\hline \multirow{3}{*}{ I } & основна 1 (вересень 2012 р.) & 6,03 & 0,33 & 9,71 & 0,34 \\
\hline & основна 2 (вересень 2013 р.) & 5,97 & 0,14 & 9,78 & 0,29 \\
\hline & основна 3 (вересень 2014 р.) & 6,03 & 0,15 & 9,78 & 0,18 \\
\hline \multirow{3}{*}{ II } & основна 1 (вересень 2013 р.) & $5,47 *$ & 0,43 & $9,47 *$ & 0,44 \\
\hline & основна 2 (вересень 2014 р.) & $5,81^{*}$ & 0,16 & $9,63 *$ & 0,21 \\
\hline & основна 3 (вересень 2015 р.) & $5,83^{*}$ & 0,14 & $9,58 *$ & 0,11 \\
\hline
\end{tabular}

Примітка. * - p<0,05 при порівняння показників учасників однієї групи на різних етапах експерименту.

При цьому, виявлено статистично значущу різницю між середньо груповими результатами проходження змагальної дистанції 380 м учасниками основної та контрольної груп на користь юних спортсменів основних груп в усіх трьох річних макроциклах тренування (рис. 1).

Так, наприкінці річного макроциклу підготовки 2012-2013 pр. середньо груповий результат проходження змагальної дистанції учасниками основної групи виявився на 3,02 с або на 4,96\% кращим, ніж відповідний результат учасників контрольної групи; результат учасників основної групи 2013-2014 рр. на 5,25 с (7,92\%), перевищував відповідний результат учасників контрольної групи; протягом 2014-2015 рр. Юні велосипедисти ВMX на змаганнях показали на 5,25 с $(7,82 \%)$ кращий результат, ніж відповідний результат учасників контрольної групи. Усі отримані розходження були статистично значущими $(\mathrm{p}<0,01)$.

Відповідно до отриманих результатів за тестом Т. Елерса на виявлення мотивації до досягнення успіху та уникнення невдач, у групі обстежуваних 54\% від загальної 
кількості складали юні велосипедисти ВМХ з високим рівнем мотивації до досягнення успіху, натомість 45\% характеризувалися високим, 38\% - середнім і 17\% - низьким рівнем мотивації до уникнення невдач.

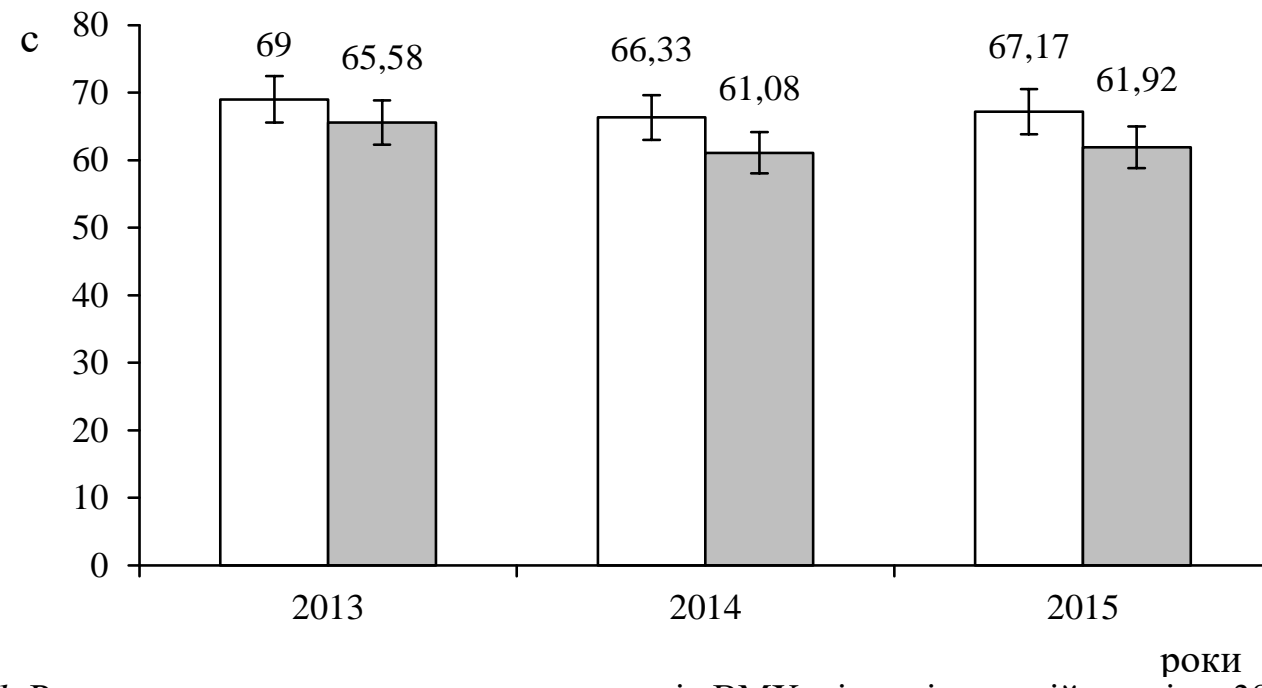

Рuc. 1. Результати змагань юних велосипедистів ВМХ в індивідуальній гонці на 380 м. наприкінці річних макроциклів тренування, $n=24$ : $\square$ - основна група.

Ми схиляємось до думки, що поєднання фізичних та психологічних впливів справляли неоднакові зміни в окремих органах і системах організму, а в підсумку цілісний організм так інтегрував діяльність задіяних протягом річного макроциклу тренування функціональних систем, що синергія одночасних навантажень на різні органи і системи змісту авторської програми відобразилася в кращих, порівняно з програмою ДЮСШ, результатах розвитку швидкісних і координаційних здібностей та змагальній діяльності юних велосипедистів ВМХ.

Отримані дані дозволяють підтвердити думку багатьох дослідників різних наукових шкіл В.М. Платонова [20] А.М. Козак [10] про те, що неодмінною умовою ефективного розвитку координаційних здібностей є застосування в навчально-тренувальному процесі спеціальних вправ. Водночас треба відзначити, що найбільш сенситивним віком для розвитку координаційних здібностей юних спортсменів, які займаються в групах початкової підготовки з велосипедного спорту ВМХ є період від 9 до 10 років, а не 12 років, як це стверджують О.М. Колумбет [11] і В.М. Кириченко [5]. При цьому на рівень розвитку координації рухів у юних велосипедистів суттєвий вплив мають швидкісні здібності і це знаходить своє підтвердження в дослідженнях А.А. Горского [4] Ю.І. Іванишина [6].

\section{Висновки.}

1. Розроблено авторську програму розвитку спеціальних фізичних якостей 3 використанням двокомпонентного психофізичного впливу на розвиток координаційних здібностей юних спортсменів 3 велоспорту ВMX на початковому етапі підготовки. Принципова відмінність змісту якої від раніше використовуваних у практиці тренувань 3 цього виду спорту та інших видів велосипедного спорту полягає в наявності двох комплексно застосовуваних засобів координаційної підготовки, а саме: фізичних вправ у стрибках на батуті, застосованих як додаток до програми ДЮСШ, та психологічних вправ, спрямованих на створення мотивації до виконання фізичних вправ у стрибках на батуті, яку вперше застосовано на практиці як додаток до програми ДЮСШ в навчаль- 
но-тренувальному процесі протягом першого в житті річного макроциклу тренування юних спортсменів ВМХ.

2. Доведено, що вплив розробленої та застосованої на практиці протягом першого в житті річного макроциклу тренування 3 велосипедного спорту ВМХ в групах початкової підготовки авторської програми двокомпонентного психофізичного впливу на розвиток координаційних здібностей не обмежується підвищенням рівнів розвитку швидкісних і координаційних здібностей учнів віком 9-10 років, зареєстрованих в штучних умовах тестування, а проявляється також в кращих результатах у природних умовах змагань 3 велосипедного спорту ВMX, де середньо групові результати учасників основних груп, які тренувалися за цією програмою, були вищими в порівнянні 3 результатами учасників контрольних груп, які тренувалися за програмою ДЮСШ.

3. Застосування комплексу методів психологічної мотивації велосипедистів-початківців ВMX до виконання неспецифічних для велоспорту ВМХ вправ із стрибків на батуті, заснованих на використанні вербальних засобів психологічної підготовки спортсменів, зумовило інтеграцію діяльності задіяних протягом річного макроциклу тренування фізіологічних систем цілісного організму, що стало підгрунтям для кращих, порівняно з програмою ДЮСШ, результатів розвитку рухових здібностей, провідних для велосипедного спорту ВМХ та змагальної діяльності.

Перспективи подальших досліджень в обраному напрямі вбачаються у виявленні особливостей i, відповідно, вдосконаленні розробленої методики розвитку швидкісних i координаційних здібностей як додаткового засобу для застосування в тренувальному процесі велосипедистів ВМХ в групах базової підготовки.

1. Білієнко АГ. Біомеханіка вертикальної стійкості і оцінка її в спорті: дис. на здобуття вч. ступеня канд. пед. наук: 13.00.04. “Терія і методика фізичного виховання, спортивного тренування та оздоровчої адаптивної фізичної культури”. Санкт-Пітер., 2008. 212 с.

2. Булатов ПП, Лукша ЕП. Методика развития скоростно-силовых способностей у юных гонщиков ВМХ. Молодая спортивная наука Беларуси. Материалы междунар. науч. конф. Минск; 2014: 29-31.

3. Воропай СМ. Вплив тренувальних навантажень різної переважної спрямованості на корекцію психофізіологічного стану юних спортсменів. Спортивний вісник Придніпров'я. 2016; 1: 164-169.

4. Горский AA. Методика развития координационных способностей велосипедистов BMX-RACE на начальном этапе спортивной подготовки [автореферат]. Омск; 2015. 20 с.

5. Дерюгин В. Система методов психологического воздействия. URL: http://psychology.net.ru/articles/ content/1105305530.html.

6. Іванишин ЮІ. Вплив занять екстремальними видами рухової активності на розвиток координаційних здібностей підлітків [автореферат]. Київ; 2018. 24 с.

7. Кашуба В, Гордеева М, Жук А, Ризатдинова А, Литвиненко Ю. Программа повышения эффективности техники двигательных действий в видах спорта со сложнокоординационной структурой движения. Revistă teoretico-tiinţifică "Stiinţa culturii fizice". 2017;27(1): 93-8.

8. Кириченко ВМ. Педагогічні умови вдосконалення координаційних здібностей школярів. 2015; 42 (95): 475-480.

9. Ковылин ММ, Передельский АА. Психофизическая диагностика и технико-тактильный анализ как управляющий механизм экспериментального педагогического программирования в велоспорте (ВМХ). Теория и практика физической культуры. 2014; 1: 36-38.

10. Козак АМ. Контроль координаційних здібностей тенісистів 5-6 років на етапі початкової підготовки [автореферат]. Київ; 2016. 20 с.

11. Колумбет ОМ. Розвиток координаційних здібностей молоді: монографія. Київ: Освіта України, 2014. $420 \mathrm{c}$.

12. Круцевич ТЮ. Теорія і методика фізичного виховання. Київ: Олімпійська література; 2008. 368 с.

13. Кушнір Я. Формуваня координаційних здібностей молодших школярів спеціальної медичної групи. Фізичне виховання, спорт і культура здоров'я у сучасному суспільстві. 2015; 4 (32): 90-94.

14. Лях ВИ. Двигательные способности школьников. Москва: Терра-Спорт; 2000. 192 с.

15. Матвеев О. Психология влияния на человека 2012. URL: http://психоаналитик-матвеев.pф/ psychologiya/psikhologiya-vliyaniya-na-cheloveka/. 
16. Медведев, ВГ, Дышаков АС. Техника стартового действия в ВMХ-Race. Экстремальная деятельность. 2017; 1 (42): 45-48.

17. Мельников ВМ, редактор. Психология: учеб. для ИФК. Москва: Физкультура и спорт; 1987. 367 с.

18. Пионтковский Д, Мыцкан Б. Развитие координационных способностей младших школьников в велоспорте ВMX с помощью методики дополнительной психофизической тренировки. In: Manolachi V, redactor. Sport. Olimpism. Sanatate, congress scientific international (2016; Chisinau). Sport. Olimpism. Sanatate: Congres Scientific International: Consecrate anniversaries a 65 -a a organizarii in vatamantului superior de culturafizica din Republica Moldova, 5-8 octombrie 2016. Chisinau: USEFS; 2016; 2: $277-282$.

19. Піонтковський ДВ. Специфіка розвитку психофізіологічних функцій організму дітей молодшого віку, які займаються BMX-RACE. B: Актуальні проблеми фізичного виховання і спорту в сучасних умовах. Матеріали I Міжнар. наук.-практ. конф. Дніпропетровськ, 2015; 270-271.

20. Платонов ВН. Система подготовки спортсменов в олимпийском спорте. Общая теория и ее практические приложения. К: Олимпийская литература, 2015. Т. 1. 680 с.

21. Про державні тести і нормативи оцінки фізичної підготовленості населення України: постанова Кабінету Міністрів України від 15 січня 1996 р. № 80.

22. Прудникова МС. Особенности, проблемы и перспективы развития экстремального вида велосипедного спорта (ВМХ). Слобожанський науково-спортивний вісник. 2014; 2(40): 111-116.

23. Родионов АВ. Практическая психология физической культуры и спорта. Махачкала: Юпитер; 2002. $158 \mathrm{c}$.

24. Родионов АВ. Психология физического воспитания и спорта: учебник. Москва: Академический Проект; 2004. 576 с.

25. Сизова ВЮ. Формирование двигательного навыка при обучении спортивной технике. Науковий часопис Нац. пед. ун-ту імені М. П. Драгоманова. Серія 15, Науково-педагогічні проблеми фізичної культури (фізична культура і спорт). Зб. наук. пр. Київ; 2013; 7 (33): 223-229.

26. Чалдини Р, Мартин С, Гольдштейн Н. Психология убеждения. 50 доказанных способов быть убедительным. Москва: Манн, Иванов и Фербер; 2013. 224 с.

27. Louis J, Billaut F, Bernad T, et al. Physiological demands of a simulated BMX competition. Int J Sports Med. 2013; 34 (6): 491-496.

28. Smoll FL, Smith RE, Cumming, SP. Effects of a psych educational intervention for coaches on changes in child athletes' achievement goal orientations. Journal of Clinical Sport Psychology. 2007; 1: 23-46.

29. Smoll FL, Smith, RE. Sports psychology for youth coaches. Washington: National Federation for Catholic Youth Ministry; 1987.

30. Weiss MR. Psychological skill development in children and adolescents. The Sports Psychologist. 1991; 5: 335-354.

\section{References}

1. Biliienko AH. Biomekhanika vertykalnoi stiikosti i otsinka yii v sporti: dys. na zdobuttia vch. stupenia kand. ped. nauk: 13.00.04. "Teriia i metodyka fizychnoho vykhovannia, sportyvnoho trenuvannia ta ozdorovchoi adaptyvnoi fizychnoi kultury". Sankt-Piter., 2008. 212 s.

2. Bulatov PP, Luksha EP. Metodyka razvytyia skorostno-sylovыkh sposobnostei u yunыkh honshchykov VMKh. Molodaia sportyvnaia nauka Belarusy. Materyalы mezhdunar. nauch. konf. Mynsk, 2014; $29-31$.

3. Voropai SM. Vplyv trenuvalnykh navantazhen riznoi perevazhnoi spriamovanosti na korektsiiu psykhofiziolohichnoho stanu yunykh sportsmeniv. Sportyvnyi visnyk Prydniprovia. 2016; 1: 164-169.

4. Horskyi AA. Metodyka razvytyia koordynatsyonnыkh sposobnostei velosypedystov VMKh-RACE na nachalnom эtape sportyvnoi podhotovky [avtoreferat]. Omsk; 2015. $20 \mathrm{~s}$.

5. Deriuhyn V. Systema metodov psykholohycheskoho vozdeistvyia. Dostupno: http://psychology.net.ru/ articles/content/1105305530.html.

6. Ivanyshyn YuI. Vplyv zaniat ekstremalnymy vydamy rukhovoi aktyvnosti na rozvytok koordynatsiinykh zdibnostei pidlitkiv [avtoreferat]. Kyiv; 2018. 24 s.

7. Kashuba V, Hordeeva M, Zhuk A, Ryzatdynova A, Lytvynenko Yu. Prohramma povbshenyia эffektyvnosty tekhnyky dvyhatelnыkh deistvyi v vydakh sporta so slozhnokoordynatsyonnoi strukturoi dvyzhenyia. Revistă teoretico-tiinţifică "Stiinţa culturii fizice". 2017; 27 (1): 93-98.

8. Kyrychenko VM. Pedahohichni umovy vdoskonalennia koordynatsiinykh zdibnostei shkoliariv. 2015; 42 (95): 475-480.

9. Kovylyn MM, Peredelskyi AA. Psykhofyzycheskaia dyahnostyka y tekhnyko-taktylnыi analyz kak upravliaiushchyi mekhanyzm eksperymentalnoho pedahohycheskoho prohrammyrovanyia v velosporte (VMKh). Teoryia y praktyka fyzycheskoi kulturы. 2014; 1: 36-38.

10. Kozak AM. Kontrol koordynatsiinykh zdibnostei tenisystiv 5-6 rokiv na etapi pochatkovoi pidhotovky [avtoreferat]. Kyiv; 2016. 20 s. 
11. Kolumbet OM. Rozvytok koordynatsiinykh zdibnostei molodi: monohrafiia. Kyiv: Osvita Ukrainy, 2014. $420 \mathrm{~s}$.

12. Krutsevych TIu. Teoriia i metodyka fizychnoho vykhovannia. Kyiv: Olimpiiska literatura; 2008. 368 s.

13. Kushnir Ya. Formuvania koordynatsiinykh zdibnostei molodshykh shkoliariv spetsialnoi-medychnoi hrupy. Fizychne vykhovannia, sport i kultura zdorovia u suchasnomu suspilstvi. 2015; 4 (32): 90-94.

14. Liakh VY. Dvyhatelnыe sposobnosty shkolnykov. Moskva: Terra-Sport; 2000. $192 \mathrm{~s}$.

15. Matveev O. Psykholohyia vlyianyia na cheloveka. 2012. Dostupno: http://psykhoanalytyk-matveev.rf/ psychologiya/psikhologiya-vliyaniya-na-cheloveka/.

16. Medvedev, VH, Dushakov AS. Tekhnyka startovoho deistvyia v BMX-Race. Ekstremalnaia deiatelnost. 2017; 1 (42): 45-48.

17. Melnykov VM, redaktor. Psykholohyia: ucheb. dlia YFK. Moskva: Fyzkultura y sport; 1987. 367 s.

18. Pyontkovskyi D, Mytskan B. Razvytye koordynatsyonnыkh sposobnostei mladshykh shkolnykov v velosporte VMKh s pomoshchiu metodyky dopolnytelnoi psykhofyzycheskoi trenyrovky. In: Manolachi V, redactor. Sport. Olimpism. Sanatate, congress scientific international (2016; Chisinau). Sport. Olimpism. Sanatate: Congres Scientific International: Consecrate anniversaries a 65 -a a organizarii in vatamantului superior de culturafizica din Republica Moldova, 5-8 octombrie 2016. Chisinau: USEFS; 2016; 2: $277-282$.

19. Piontkovskyi DV. Spetsyfika rozvytku psykhofiziolohichnykh funktsii orhanizmu ditei molodshoho viku, yaki zaimaiutsia VMKh-RACE. V: Aktualni problemy fizychnoho vykhovannia i sportu v suchasnykh umovakh. Materialy I Mizhnar. nauk.-prakt. konf. Dnipropetrovsk, 2015; 270-271.

20. Platonov VN. Systema podhotovky sportsmenov v olympyiskom sporte. Obshchaia teoryia y ee praktycheskye prylozhenyia. K: Olympyiskaia lyteratura, 2015. T. 1. $680 \mathrm{s.}$

21. Pro derzhavni testy i normatyvy otsinky fizychnoi pidhotovlenosti naselennia Ukrainy: postanova Kabinetu Ministriv Ukrainy vid 15 sichnia 1996 r. № 80.

22. Prudnykova MS. Osobennosty, problemы у perspektyvы razvytyia эkstremalnoho vyda velosypednoho sporta (VMKh). Slobozhanskyi naukovo-sportyvnyi visnyk. 2014; 2 (40): 111-116.

23. Rodyonov AV. Praktycheskaia psykholohyia fyzycheskoi kulturы y sporta. Makhachkala: Yupyter; 2002. $158 \mathrm{~s}$.

24. Rodyonov AV. Psykholohyia fyzycheskoho vospytanyia y sporta: uchebnyk. Moskva: Akademycheskyi Proekt; 2004. 576 s.

25. Syzova VIu. Formyrovanye dvyhatelnoho navыka pry obuchenyy sportyvnoi tekhnyke. Naukovyi chasopys Nats. ped. un-tu imeni M. P. Drahomanova. Seriia 15, Naukovo-pedahohichni problemy fizychnoi kultury (fizychna kultura i sport). Zb. nauk. pr. Kyiv; 2013; 7 (33): 223-229.

26. Chaldyny R, Martyn S, Holdshtein N. Psykholohyia ubezhdenyia. 50 dokazannykh sposobov byt ubedytelnym. Moskva: Mann, Yvanov y Ferber; 2013. 224 s.

27. Louis J, Billaut F, Bernad T, et al. Physiological demands of a simulated BMX competition. Int J Sports Med. 2013; 34 (6): 491-496.

28. Smoll FL, Smith RE, Cumming, SP. Effects of a psych educational intervention for coaches on changes in child athletes' achievement goal orientations. Journal of Clinical Sport Psychology. 2007; 1: 23-46.

29. Smoll FL, Smith, RE. Sports psychology for youth coaches. Washington: National Federation for Catholic Youth Ministry; 1987.

30. Weiss MR. Psychological skill development in children and adolescents. The Sports Psychologist. 1991; 5: 335-354.

\section{Цитування на цю статтю:}

Піонтковський ДВ, Мицкан БМ, Мицкан ТС. Розвиток швидкісних і координаційних здібностей спортсменів з велосипедного спорту ВМХ на етапі початкової підготовки. Вісник Прикарпатського університету. Серія: Фізична культура. 2019 Листоп 27; 34: 111-124

\begin{tabular}{|c|c|}
\hline Відомості про автора: & Information about the author: \\
\hline $\begin{array}{l}\text { Піонтковський Дмитро Валерійович - Гумані- } \\
\text { тарний інститут Національного авіаційного універ- } \\
\text { ситету (Київ, Уклаїна) }\end{array}$ & $\begin{array}{l}\text { Piontkovskyi Dmytro Valeriiovych - Humanities } \\
\text { Institute of National Aviation University (Kiev, } \\
\text { Uklaine) }\end{array}$ \\
\hline \multicolumn{2}{|l|}{$\begin{array}{l}\text { e-mail: dima.zacepin@ukr.net } \\
\text { https://orcid.org/0000-0002-5853-7135 }\end{array}$} \\
\hline $\begin{array}{l}\text { Мицкан Богдан Михайлович - доктор біологічних } \\
\text { наук, професор, завідувач кафедри теорії та мето- } \\
\text { дики фізичної культури і спорту, ДВНЗ “При- } \\
\text { карпатський національний університет ім. Василя } \\
\text { Стефаника" (Івано-Франківськ, Україна) }\end{array}$ & $\begin{array}{l}\text { Mytskan Bohdan Mykhailovych - Doctor of Bio- } \\
\text { logical Science, Professor, Head of Chair of Theory } \\
\text { and Methods of Physical Training and Sports, Vasyl } \\
\text { Stefanyk Precarpathian National University (Ivano- } \\
\text { Frankivsk, Ukraina) }\end{array}$ \\
\hline
\end{tabular}


e-mail: bogdanmytskan21@gmail.com

https://orsid.org/0000-0002-5853-713X

Мицкан Тетяна Степанівна - кандидат психологічних наук, доцент, ДВНЗ “Прикарпатський національний університет імені Василя Стефаника" (Івано-Франківськ, Україна)

e-mail: tania_mytskan@ukr.net

http://orcid.org/0000-0002-4164-2961

УДК 796.093.554

doi: 10.15330/fcult.34.124-130

Mytskan Tetiana Stepanivna - Candidate of Science (Psychology), Associate Professor (Ph. D.), Vasyl Stefanyk Precarpathian National University (IvanoFrankivsk, Ukraine)

\title{
АНАЛІЗ ПРАКТИЧНОГОДОСВІДУ РОЗВИТКУ КООРДИНАЦЙНИХ ЗДІБНОСТЕЙ У СПОРТСМЕНІВ-МАУНТИНБАЙКЕРІВ НА ЕТАПІ СПЕЦІАЛІЗОВАНОЇ БАЗОВОЇ ПІДГОТОВКИ
}

\begin{abstract}
Мета - проаналізувати уявлення тренерів та спортсменів про розвиток координаційних здібностей на етапі спеціалізованої базової підготовки у маунтинбайку. Методи: аналіз науково-методичної літератури, анкетування спортсменів та тренерів з різним досвідом роботи. Результати. Визначено, щзо важливим компонентом координаційних здібностей є здатність оцінювати і регулювати просторові, часові, динамічні параметри рухів та спритність, розвитку яких потрібно приділяти найбільше уваги. Визначено місие координаційних здібностей у спортивній підготовиі: на 10 балів їх вплив на результат у маунтинбайку оцінили 20\% тренерів, на 9-26\%. Висновок. У тренувальному процесі необхідно приділяти достатньо уваги розвитку координаційних здібностей та їх компонентів.
\end{abstract}

Ключові слова: координаційні здібності, маунтинбайк, спритність.

The purpose is to analyze the coaches and athletes perceptions of the development of coordination abilities at the stage of specialized basic training in mountainbike (in the example of cross-country), to determine what forms of development of coordination abilities athletes-mountainbikers prefer. Methods: analysis of scientific and methodological literature, questioning of athletes $(n=67)$ and coaches $(n=35)$ with different work experience. Results. Trainers with work experience of 9 years and over have determined that the most important component of developmental coordination abilities that needs to be given the most attention is the ability to evaluate and adjust the spatial, spatio-temporal, dynamic parameters of movements, agility and the ability to arbitrarily relax muscles, and the least significant component is the ability to sense and absorb rhythm. With respect to determining the place and role of coordination abilities and their components in the cyclist's sports training system, the following points were determined on a 10 point scale: only $8 \%$ rated the role of coordination abilities and their impact on mountain bike sport (in cross-country): by $9-26 \%$ and by a maximum of 10 points $20 \%$ of the coaches surveyed. During the questioning of the athletes it is revealed that they favor the forms of development of coordination skills, which are performed directly on the bicycle and are most similar in structure to competitive activity (training on special competitive tracks with complex technical sections. Conclusion. Thus, in the training process of mountain bikers, it is necessary to pay sufficient attention to the development of coordination abilities, as they affect the effectiveness of competitive activities.

Keywords: coordination abilities, moutainbike, agility.

Постановка проблеми й аналіз результатів останніх досліджень. Зростаюча конкуренція на міжнародній спортивній арені, зміна рельєфу змагальних трас та складності їх проходження, з одного боку, та недостатня кількість наукових робіт 3 методики підготовки велосипедистів до специфічних особливостей змагальної діяльності, з іншої, обумовлюють необхідність розробки нових методик, комплексів вправ для вдосконалення процесу розвитку координаційних здібностей спортсменів в олімпійській дисципліні крос-кантрі, де змагальна траса складається з комбінації природних та штучних перешкод з урахуванням особливостей місцевості і включає лісові та лугові стежки, грунтові дороги, гравійні доріжки, підйоми та спуски тощо 3 кожним роком складність змагальних трас на головних міжнародних змаганнях підвищується [1]. 